\title{
Mikrodalga ve pastörizasyon uygulamalarının siyah havucun kalite parametreleri üzerine etkilerinin belirlenmesi
}

\section{Determination of the influences of microwave and pasteurization applications on quality parameters of black carrot}

\author{
Filiz UÇAN TÜRKMEN ${ }^{* 1}$ iD , Hatice Aysun MERCIMEK TAKCl ${ }^{2}$, Sümeyye ÖZMERMER ${ }^{1}$ iD, \\ Yasemin BOZKURT $^{1}$ iD, Ayşegül GÜNERi ${ }^{1}$ iD , Zeliha ELAGÖZ $^{1}$ iD
}

${ }^{1}$ Kilis 7 Aralık University, Engineering and Architecture Faculty, Food Engineering Department, 79000, Kilis, Turkey

${ }^{2}$ Kilis 7 Aralık University, Arts and Sciences Faculty, Molecular Biology and Genetics Department, 79000, Kilis, Turkey

\section{To cite this article:}

Uçan Türkmen, F., Mercimek Takcl, H.A., Özmermer, S., Bozkurt, Y., Güneri, A., Elagöz, Z., 2018. Mikrodalga ve pastörizasyon uygulamalarının siyah havucun kalite parametreleri üzerine etkilerinin belirlenmesi. Harran Tarim ve Gida Bilimleri Dergisi, 22(2): 196-206

\section{Address for Correspondence: Filiz UÇAN TÜRKMEN e-mail: \\ ucanfiliz@gmail.com}

Received Date:

21.06.2017

Accepted Date:

08.03.2018

(C) Copyright 2018 by Harran University Faculty of Agriculture. Available on-line at www.dergipark.gov.tr/harranziraat
Öz

Bu çalışmada siyah havuca pastörizasyon ve mikrodalga uygulama olmak üzere iki farklı ön işlem uygulanmıştır. Uygulanan bu işlemler sonucunda siyah havuç örneklerinin, POD (peroksidaz), PME (pektinmetilesteraz), pH değeri, SÇKM (suda çözünür kuru madde), toplam titrasyon asitliği, \% nem tayini, askorbik asit, toplam fenolik madde miktarı, toplam flavonoid madde miktarı, toplam monomerik antosiyanin miktarı, antioksidan kapasite değeri, renk ve HMF (hidroksimetilfurfural) özelliklerinin değişimi incelenmiştir. Araştırma sonucunda, pastörizasyon ön işlemi uygulanan örneklerde; $\mathrm{pH}$, $\%$ nem, antioksidan, toplam monomerik antosiyanin ve renk $(a, b)$ değerlerinde artış gözlemlenmiştir. Ayrıca mikrodalga ön işlemi uygulanan örneklerde; SÇKM, PME, HMF, toplam fenolik, toplam flavonoid, askorbik asit ve renk ( $L$, hue ve kroma) değerlerinde artış gözlemlenmiştir.

Anahtar Kelimeler: Siyah havuç, Pastörizasyon, Mikrodalga, Antioksidan, Peroksidaz

\section{ABSTRACT}

In this study, two different pre-treatments; pasteurization and microwave application were applied to black carrots. Following these treatments, the black carrot samples were analyzed in the context of POD (peroxidase), PME (pectinmethylesterase), $\mathrm{pH}$, WSDM (water soluble dry matter), total titration acidity,\% moisture content, ascorbic acid, total phenolics, total flavonoid, total monomeric anthocyanin, antioxidant activity, color and HMF (hydroxymethylfurfural). As a result of the research, in pasteurized samples: Increases were observed in $\mathrm{pH}, \%$ moisture content, antioxidant, total monomeric anthocyanin and color $(a, b)$ values. Also, in microwave processing applied samples, increase were observed in WSDM, PME, HMF, total phenolics, total flavonoid, ascorbic acid and color (L, hue and croma) values.

Key Words: Black carrot, Pasteurization, Microwave, Antioxidant, Peroxidase

\section{Giriş}

Havuç, Apiaceae (Umbelliferae) familyasından iki yıllık bir bitki olup bilimsel adı Daucus carota'dır
(Tangüler, 2010). Havuç, köksü sebze bitkilerinden biridir. Botanik sınıflandırmaya göre havuç iki gruba ayrılmaktadır. Bu gruplar; Türkiye, Afganistan, Mısır, Pakistan ve Hindistan'da 
geleneksel olarak yetiştirilen antosiyanin (doğuya ait) grup (Daucus carota ssp. sativus var. atrorubens Alef.) ve dünya genelinde yetiştirilen karoten (batıya ait) grup (Daucus carota ssp. sativus var. sativus)'tur. Antosiyanin grubuna ait havuçlar mor antosiyanin pigmentlerine sahiptir (Ağçam ve Akyıldız, 2015). Ülkemizde önemli miktarda üretimi yapılan ve insan beslenmesinde önemli olan siyah havuç, renklendirici yapımında kullanılmak üzere yurtdışına ham madde olarak gönderilmektedir. Bu amaçla yıkanıp paketlenen siyah havuçlar taze olarak yurtdışına ihraç edilmektedir (Demir, 2010).

Gıda proseslerinde yaygın olarak kullanılan ısıl işlem uygulamalarının başında haşlama işlemi gelmektedir. Haşlama, gıda maddelerinin atmosfer basıncı altında $100^{\circ} \mathrm{C}^{\prime}$ de su ya da buhar içerisinde kısa süreler tutulması ile minimum $54.4^{\circ} \mathrm{C}^{\prime}$ nin üzerinde gerçekleşen işlem olarak tanımlanmaktadır. Bu işlem, sebzelerin işlenmesinde en önemli basamağı oluşturmaktadır (Negi ve Roy, 2000). Haşlama ile inaktive edilmesi hedeflenen enzimlerin en başında peroksidaz (POD) gelmektedir. Isıya en dirençli enzim olan POD, haşlama prosesinin yeterliliğini belirlemede indikatör olarak kullanılmaktadır. Bu enzim, oksijen ya da peroksidi hidrojen alıcısı olarak kullanarak oksidatif reaksiyonları katalizleyen ve fenolik bileşiklerde kahverengi polimer oluşumuna neden olan bir enzimdir (Tomas-Barberan ve Espin, 2001). POD, hidrojen peroksiti kullanarak organik ve inorganik substratların yanı sıra fenoller (guaiacol, p-kresol) ve aromatik aminler (anilin, odianisidin) gibi çok sayıda aromatik bileşiklerin de oksidasyonunu katalizler (Yemenicoğlu ve Cemeroğlu, 1998). POD enzimi ayrıca bazı gıda bileşenleri ( $C$ vitamini, karotenoidler ve yağ asitleri) ile reaksiyona girmekte ve bazı besin maddelerinin kayıplarına yol açmaktadır (Murcia, 2000).

Taze buhar uygulaması veya kaynayan suya daldırma gibi geleneksel yöntemler haşlama işleminde hala yaygın bir şekilde kullanılmasına rağmen, son yıllarda yeni bir yöntem olarak mikrodalga işlemi de uygulanmaktadır. Bu işlem ile suya çok az veya hiç gerek duymaksızın ısı transferi etkili bir şekilde gerçekleşmektedir (Li ve Brewer, 2005). Mikrodalgalar, elektromanyetik spektrumun bir parçası olup görünür ışık ile radyo dalgaları arasında yer almaktadır. Dalga boyları $1 \mathrm{~mm}-1 \mathrm{~m}$ ve frekansları $300 \mathrm{MHz}-300 \mathrm{GHz}$ arasında değişmekte olan mikrodalgaların ısıtma frekansları endüstriyel, bilimsel ve tıbbi kullanımlar için belirlenmiştir (Kemahlıoğlu ve Baysal, 2002).

Mikrodalga uygulamasının en önemli özelliği, ısı üretiminin moleküler düzeyde başlaması olarak bilinmektedir. İçten ısınma sağlandığı için de sıcaklık dağılımının daha homojen olduğu ve yüzeyin aşırı ısınmasının engellendiği bilinmektedir. Bu sayede hem zamandan hem de enerjiden tasarruf sağlanmaktadır (Gümüşderelioğlu, 2012). Mikrodalga işleminin birçok avantajı vardır. Bunlardan biri; haşlama işlem süresinin önemli ölçüde azalması olarak bilinmektedir. Mikrodalga uygulamasının diğer bir avantajı ise; haşlama sırasında üründeki çözünebilir bileşiklerin çözünürlüklerini oldukça azaltması ve bu bileşiklerin gıdanın yapısında daha çok tutulmasını sağlamasıdır. Mikrodalga ile haşlanan ürünlerin tekstürel özelliklerinin kabul edilebilir sınırlar içinde olması bu uygulamanın diğer bir avantajıdır. Ayrıca hedef sıcaklığa ulaşmak için gerekli mikrodalga işleminin daha kısa sürede gerçekleşmesine bağlı olarak üründe tat ve aroma kaybının daha az olduğu belirtilmiştir (DorantesAlvarez, 2005). Mikrodalga ile yapılan haşlama işleminin bazı dezavantajları da vardır. Bunlar; özellikle ıspanak ve lahana gibi yapraklı sebzelerde ürün yüzeyinin kuruması meyvelerde karamelizasyonun meydana gelmesi, ürünün boyutuna ve şekline bağlı olarak heterojen olarak ısınmasıdır (Fito, 2005).

$\mathrm{Bu}$ çalışmada, mikrodalga ve pastörizasyon uygulamalarının POD, PME, pH değeri, SÇKM, titrasyon asitliği, \% nem, askorbik asit, toplam fenolik madde miktarı, toplam flavonoid madde miktarı, toplam monomerik antosiyanin miktarı, antioksidan kapasite değeri, renk ve HMF olmak üzere bazı kalite parametrelerine etkilerinin araştırılması amaçlanmıştır. 


\section{Materyal ve Yöntem}

\section{Materyal}

Çalışmada Çukurova bölgesinden temin edilen "Siyah Havuç (Daucus corata L.)" kullanılmıştır. Siyah havuçlar işleninceye kadar Kilis 7 Aralık Üniversitesi, Mühendislik-Mimarlık Fakültesi Gıda Mühendisliği Bölümü Laboratuvarında $+4{ }^{\circ} C^{\prime}$ de depolanmıştır. Havuçlar ayıklama, yıkama ve dilimleme ön işlemlerinden geçirilmiştir. Havuçlar $5 \pm 0.5 \mathrm{~mm}$ küp şeklinde doğranarak dilimleme işlemi gerçekleştirilmiştir.

\section{Yöntem}

Çalışmamızda farklı uygulamalar aşağıda tanımlandığı gibi kullanılmıştır: Pastörizasyon Uygulama, Mikrodalga Uygulama ve Kontrol.

Pastörizasyon Uygulama: Havuç dilimlerinde pastörizasyon işlemi ön denemelerle belirlenen sürede gerçekleştirilmiştir. Laboratuvar ölçekli Isıtıcı (Wisd, WSB-30, Korea) üzerinde, $98^{\circ} \mathrm{C}^{\prime}$ de kaynayan $10 \mathrm{ml}$ saf su ve $5 \mathrm{~g}$ örnek ile 0-600 saniye boyunca her 60 saniyede bir POD (peroksidaz) aktivitesi kontrol edilerek uygulanmıştır.

Enzimin endüstriyel uygulamalarda indikatör olarak kullanılması nedeniyle ön denemelerde, POD'un \%100 inaktive olduğu koşullar seçilmiştir.

$\mathrm{Bu}$ işlemden sonra tüm örnekler soğutularak analize tabi tutulmuştur. Pastörizasyon işleminin parametreleri de bu koşullara göre 5 gram örnek için $10 \mathrm{ml}$ saf su ve 240 saniye işlem süresi şeklinde sabitlenmiştir.

\section{Mikrodalga uygulama}

Mikrodalga işlemi, pastörizasyon koşulları temel alınarak ön denemelerle \%100 POD inaktivasyonu hedeflenerek gerçekleştirilmiştir.

İslem, $1000 \mathrm{~W}$ güç ve $2450 \mathrm{MHz}$ frekansta çalışan ev tipi AKAl marka mikrodalga fırında, uygun cam kap içerisinde gerçekleştirilmiştir. Her denemede haşlama kabı döner tablanın ortasına konularak işlem yapıldığı için işlemler sırasında ısının homojen şekilde dağıldığı varsayılmıştır. Haşlanan havuçlar soğutularak analizlere tabi tutulmuştur. Yöntemlerin fiziksel ve kimyasal açıdan kıyaslanması için çalışma üç farklı grup ile yürütülmüştür: (i) kontrol grubu (hiçbir ısıl işleme tabi tutulmayan) (ii) Mikrodalga grubu (Pastörizasyon etkinliğinin karşılaştırmalı olarak belirlenmesi amacıyla); (iii) Pastörizasyon grubu (Mikrodalga etkinliğinin karşılaştırmalı olarak belirlenmesi amacıyla) (Sezer, 2014).

Örneklerin adlandırılmaları ise şu şekildedir: "pastörize havuç suyu (PAS. H.S.), pastörize posa suyu (PAS. P.S.), mikrodalga posa suyu (MiK. P.S.), mikrodalga havuç suyu (MiK. H.S.) ve kontrol (K)".

\section{Analizler}

\section{$P O D$ inaktivasyonu (Haşlama yeterlilik testi)}

Örneklerden $5 \mathrm{~g}$ alınıp, $5 \mathrm{~mm}$ küp şeklinde doğranarak bir tüpe konulmuştur. Tüpe $5 \mathrm{ml}$ saf su, $1 \mathrm{ml} \% 1$ guaiacol (Sigma-AldrichCorp, USA) ve $1 \mathrm{ml}$ \%0.5'lik $\mathrm{H}_{2} \mathrm{O}_{2}$ çözeltisi eklenip 5 dakika bekletilmiştir. Herhangi bir renk değişiminin olmadığı süreye kadar haşlama işlemine devam edilmiştir (Cemeroğlu, 1992).

\section{pH tayini}

$\mathrm{pH}$ değeri tayini cam elektrotlu ISOLAB marka pH metre kullanılarak ölçülmüştür (Cemeroğlu, 2007).

\section{Suda çözünür kuru madde (SÇKM) miktarı}

Suda çözünür kuru madde miktarı masa tipi Abbe refraktometresi (J.P. SELECTA, s.a. marka) ile $20^{\circ} C^{\prime}$ de belirlenmiştir. Sonuçlar ${ }^{\circ} B$ olarak ifade edilmiştir (Cemeroğlu, 2007).

\section{Titrasyon asitliği (TA) tayini}

$5 \mathrm{ml}$ havuç suyu alınarak $0.1 \mathrm{~N} \mathrm{NaOH}$ çözeltisi ile pH 8.1' e kadar titre edilmiş ve sonuçlar, g $(100 \mathrm{ml})$ ${ }^{1}$ olarak hesaplanmıştır (Sànchez-Moreno, 2003).

\section{\% Nem miktarı}

Kurutma kabı içerisindeki $2 \mathrm{~g}$ örneğin etüvde $105{ }^{\circ} \mathrm{C}^{\prime}$ de sabit tartıma gelinceye kadar $\left(0.000^{\sim}\right.$ gram) tutulması prensibine dayanmaktadır. $\mathrm{Bu}$ süre sonunda örnek kapları desikatörde oda sıcaklığa getirilerek tartılmıştır. Örneklerdeki nem miktarı (\%, $\mathrm{g} \mathrm{g}^{-1}$ ) olarak hesaplanmıştır (AOAC, 2000). 
Askorbik asit tayini

Örneklerin L-askorbik asit içeriği $518 \mathrm{~nm}$ dalga boyunda spektrofotometre (Biochrom, LibraS60, B, England) ile 2.6-diklorofenolindofenol kullanılarak belirlenmiş ve sonuçlar $\mathrm{mg} \mathrm{I}^{-1}$ olarak ifade edilmiştir (Hışıl, 2004).

\section{Toplam fenolik madde miktarı}

Toplam fenolik madde miktarı Folin-Ciocalteu kolorimetrik metoduyla belirlenmiştir. $0.5 \mathrm{ml}$ örneğe $2.5 \mathrm{ml} \% 10^{\prime}$ luk Folin-Ciocalteu ve $2.5 \mathrm{ml}$ \%7.5'lik $\mathrm{NaHCO}_{3}$ ilave edilmiştir. $45^{\circ} \mathrm{C}^{\prime}$ de 45 dakika inkübasyondan sonra spektrofotometrede (Biochrom, Libra S60, B, England) $765 \mathrm{~nm}$ dalga boyunda metanole karşı absorbans değeri okunmuştur. Sonuçlar $\mathrm{mg} \mathrm{I}^{-1}$ gallik asit eşdeğeri (GAE) olarak ifade edilmiştir (Stankovic, 2011).

\section{Toplam flavonoid madde miktarı:}

$0.1 \mathrm{ml}$ örnek alınarak üzerine $0.9 \mathrm{ml}$ saf su 0.3 $\mathrm{mL}$ \%5' lik $\mathrm{NaNO}_{2}$ karıştırılmış ve 5 dakika bekletilmiştir. $0.6 \mathrm{ml} \% 10 \mathrm{AlCL}_{3} .6 \mathrm{H}_{2} \mathrm{O}$ karıştırılmış ve 5 dakika bekletilmiştir. Üzerine $2 \mathrm{ml} 1 \mathrm{M} \mathrm{NaOH}$ eklenilmiş ve saf su ile $10 \mathrm{ml}^{\prime}$ ye tamamlandıktan sonra $510 \mathrm{~nm}$ de okuma yapılmıştır. Sonuçlar $\mathrm{mg} \mathrm{I}^{-}$

${ }^{1}$ kateşol olarak ifade edilmiştir (Sharm, 2013).

\section{Toplam monomerik antosiyanin miktarı}

Giusti ve Wrolstad (2001) tarafından geliştirilen $\mathrm{pH}$ diferansiyel metodu kullanılmıştır.

Bu metodun ilkesi, monomerik antosiyaninlerin $\mathrm{pH} 1.0^{\prime}$ da renkli oksonium formunun, $\mathrm{pH} 4.5^{\prime}$ de ise, renksiz hemiketal formunun egemen olmasına dayanmaktadır. Buna göre, ortam pH 1.0 ve 4.5 olduğu zaman ölçülen absorbans değerlerinin farkı, doğrudan antosiyanin konsantrasyonu ile orantılı bulunmaktadır.

Absorbans okumaları siyah havuç antosiyaninlerinin maksimum absorbans verdiği dalga boyunda ( $\lambda$ vis-maks), pus (haze) halindeki bulanıklığın belirlenmesi için ise; $700 \mathrm{~nm}^{\prime}$ de yapılmıştır.

Siyah havuç antosiyaninlerin $527 \mathrm{~nm}$ 'de maksimum absorbans verdiği saptanmıştır. Monomerik antosiyanin miktarı, siyah havuç suyunda baskın bulunan siyanidin-3-glukozit cinsinden (Gil ve ark., 2000) aşağıda verilen eşitliğe göre hesaplanmıştır.

Manometrik antosiyanin miktarı $(\mathrm{mg} I-1)=\frac{\text { A.MW.SF.1000 }}{\varepsilon . L}$

A: Absorbans farkı ( $\mathrm{pH} 1.0$ ve 4.5 değerlerinde ölçülen absorbans farkı)

$\left(A=\left(A_{527}-A_{700}\right)_{p H 1}-\left(A_{527}-A_{700}\right)_{p H 4.5}\right)$

MW: Baz olarak alınacak antosiyaninin molekül ağırlığı

SF: Seyreltme faktörü

$\varepsilon$ : Molar absorpsiyon katsayısı

L: Absorbans ölçüm küvetinin tabaka kalınlığı (cm)

Siyanidin-3-glikozidin molar absorbans değeri 29600; molekül ağırlığı ise, 445.2 alınarak hesaplama yapılmıştır (Giusti ve Wrolstad 2001).

\section{Antioksidan kapasite değeri}

$0.1 \mathrm{ml}$ örnek alınarak üzerine $3.9 \mathrm{ml}$ DPPH (2,2diphenyl 1-picrylhydrazyl) $(0.025 \mathrm{~g} / \mathrm{l}$ metanolde hazırlanmış) eklenmiş ve daha sonra karışım 120 dakika karanlıkta bekletilmiştir. \% DPPH

inhibisyon $515 \mathrm{~nm}$ absorbansta okutulmuş ve hesaplama aşağıdaki formül dikkate alınarak yapılmıştır (Huang, 2005; Yılmaz, 2011).

$\%$ İnhibisyon $=\left(A_{\text {kontrol }}-A_{\text {örnek }}\right) \times 100 / A_{\text {kontrol }}$

$A_{\text {kontrol: Kontrolün absorbansı }}$

Aörnek: Örneğin absorbansı

\section{HMF tayini}

Homojenize edilen örnekten $20 \mathrm{~g}$ alınıp $100 \mathrm{ml}$ ye saf su ile seyreltilmiştir. Filtrasyon işleminden sonra 2 test tüpüne 2 'şer $\mathrm{ml}$ aktarılıp, her iki tüpe 5'er $\mathrm{ml} \mathrm{p}$-toluidin çözeltisi eklenmiştir. Tüplerden şahit olarak kullanılacak birinci tüpe $1.0 \mathrm{ml}$ saf su, ikinci tüpe $1.0 \mathrm{ml}$ barbiturik asit çözeltisi eklenmiştir. íkinci tüpün absorbansı $1 \mathrm{~cm}$ ışık yoluna sahip küvet kullanılarak, $550 \mathrm{~nm}$ 'de şahide karşı okunmuş ve saptanmıştır. Örnekteki HMF miktarı $\mathrm{mg} \mathrm{I}^{-1}$ olarak hesaplanmıştır (Cemeroğlu, 2007).

\section{Renk analizi}

Örneklerin renk değerleri "Hunterlab, miniscan EZ, USA" ile ölçülmüş, $L^{*}, a^{*}$ ve $b^{*}$ değerleri siyah ve 
beyaz plakaya göre kalibrasyon yapılarak belirlenmiştir. Bu sistemde dört filtre kullanılarak $L^{*}, a^{*}, b^{*}$ renk değerleri elde edilmektedir. $L^{*}, a^{*}, b^{*}$ değerleri üç boyutlu koordinat sistemi ile verilmekte ve bu koordinat sisteminde $\mathrm{L}^{*}$ değeri dikey eksende açıklıktan koyuluğa gidişi belirtirken, +a kırmızılığa, -a yeşilliğe, +b sarılığa, -b ise maviliğe gidişi göstermektedir (Gould, 1977). istatistiksel analiz

Analiz sonuçları, SPSS 22.0 paket programı kullanılarak varyans analizine tabi tutulmuş ve önemli bulunan farklılıklar Duncan çoklu karşılaştırma testine göre belirlenmiştir.

\section{Araştırma Bulguları ve Tartışma}

Yapılan çalışmada POD pastörizasyon uygulamada $240 \mathrm{sn}$. de, mikrodalga uygulamada ise $40 \mathrm{sn}$. de inaktif olmuştur.

POD inaktivasyonu için gerekli mikrodalga süresinin, pastörizasyona göre altı kat daha kısa sürdüğü görülmektedir (Çizelge 1). Mikrodalga uygulamasının geleneksel yönteme göre POD üzerine daha etkili olduğu belirtilmektedir (Matsui, 2008; Zheng, 2011; Benlloch-Tinoco, 2013).

Yapılan bir çalışmada, aynı koşullarda aynı sıcaklık ve süre uygulanan mikrodalga havuç örneklerinde POD enzimi geleneksel haşlama eşdeğerlerine göre daha düşük aktiviteye sahip olmuştur (Lemmens, 2009).

Ayrıca bu çalışmadaki analiz sonuçlarına bakıldığında, mikrodalga uygulamasının POD inaktivasyonu üzerine etkisinin büyük olduğu söylenebilmektedir.

Çizelge 1. Siyah havuç suyunda fizikokimyasal analizler üzerine uygulamaların etkisi

Table 1. Effect of applications on physicochemical analysis in black carrot juice

\begin{tabular}{|c|c|c|c|c|}
\hline $\begin{array}{c}\text { Uygulamalar } \\
\text { Applications }\end{array}$ & $\mathrm{pH}$ & $\begin{array}{c}\text { Suda Çözünür Kuru } \\
\text { Madde (SÇKM) }{ }^{\circ} \mathrm{B} \\
\text { Water Soluble Dry } \\
\text { Matter (WSDM) }{ }^{\circ} \mathrm{B}\end{array}$ & $\begin{array}{c}\text { Titrasyon asitliği } \\
\text { (g/100ml) } \\
\text { Titration acidity } \\
\text { (g/100ml) }\end{array}$ & $\begin{array}{c}\text { POD (sn.) } \\
\text { POD (sec) }\end{array}$ \\
\hline KONTROL & $6.78 \pm 0.00 \mathrm{a}$ & $11.2 \pm 0.2 \mathrm{a}$ & $0.54 \pm 0.06 \mathrm{a}$ & - \\
\hline PAS. H.S. & $6.59 \pm 0.00 \mathrm{c}$ & $3.2 \pm 0.0 \mathrm{e}$ & $0.13 \pm 0.02 \mathrm{c}$ & 240 \\
\hline PAS. P.S. & $6.61 \pm 0.01 \mathrm{~b}$ & $5.4 \pm 0.1 \mathrm{c}$ & $0.29 \pm 0.02 \mathrm{~b}$ & 240 \\
\hline MiK. P.S. & $6.42 \pm 0.00 \mathrm{~d}$ & $7.4 \pm 0.0 \mathrm{~b}$ & $0.28 \pm 0.01 \mathrm{~b}$ & 40 \\
\hline MiK. H.S. & $6.59 \pm 0.00 \mathrm{c}$ & $3.7 \pm 0.2 \mathrm{~d}$ & $0.09 \pm 0.01 \mathrm{~b}$ & 40 \\
\hline
\end{tabular}

Üretim aşamalarındaki (sütunlarda) farklı küçük harfler ile gösterilen örnekler asındaki farklılıklar 0.05 düzeyinde önemlidir.

The differences between samples indicated by lower-case letters in production stages (columns) are important at the 0.05 level.

Pastörize havuç suyu: PAS. H.S., Pastörize possa suyu: PAS. P.S., MiK. P.S.: Mikrodalga possa suyu, MiK. H.S.: Mikrodalga havuç suyu

Pasteurized carrot juice: PAS. H.S., Pasteurize pulp water: PAS. P.S., MIK. P.S .: Microwave pulp water, MIK. H.S .: Microwave carrot juice

Üretim aşamalarındaki (sütunlarda) farklı küçük harfler ile gösterilen örnekler arasındaki farklılıklar 0.05 düzeyinde önemlidir. Çalışmada, örneklerin $\mathrm{pH}$ değerlerinin kontrol için 6.78; pastörizasyon örnekleri için 6.59-6.61; mikrodalga örnekleri için ise 6.42-6.59 arasında olduğu bulunmuştur (Çizelge 1). Sonuçlara göre, Isıl işlem uygulanan örneklerin $\mathrm{pH}$ değerlerinin kontrol örneğine göre daha düşük olduğu tespit edilmiştir. Çağındı (2016), “mikrodalga uygulamasının kırmızı üzüm suyunun antosiyanin içeriği ile bazı fizikokimyasal özellikleri üzerine etkisi" konulu yapmış olduğu çalışmasında, kırmızı üzüm suyu örneklerinde başlangıçta pH değeri 3.90 iken; mikrodalga uygulama süresi arttıkça $\mathrm{pH}$ değerlerinin $3.83^{\prime} \mathrm{e}$ kadar azaldığı belirtilmiştir.

Geçer (2011), havuçlardaki pH değerlerinin cinsine göre değişiklik gösterdiğini belirtmekle beraber; taze havuç için 6.07; suda haşlanmış örnekleriçin 6.63; mikrodalga uygulanmış örnekler için ise $\mathrm{pH}$ değerinin 6.50 olduğu ifade edilmiştir. Çalışmadaki $\mathrm{pH}$ değerlerinin bu verilerle uyumlu olduğu görünmektedir. Çalışma kapsamında elde edilen en yüksek pH değeri kontrol örneğine aittir, en düşük $\mathrm{pH}$ değeri ise mikrodalga posa suyunda belirlenmiştir. İstatistiksel olarak incelendiğinde ise uygulamalar arasındaki farklılıklar önemli bulunmuştur $(p<0.05)$. 
Çalışmada, işlem görmemiş havuç suyu örneğinin briks değeri $11.2^{\circ} \mathrm{B}$ olarak bulunmuştur. Özkan (2009) siyah havuç suyu ile ilgili yapmış olduğu çalışmasında siyah havuç suyu briks değerini 10.98 olarak bulduğunu ifade etmiştir. Briks değerleri pastörizasyon havuç suyu ve mikrodalga havuç suyu örneklerinde sırasıyla 3.2 ve $3.7^{\circ} \mathrm{B}$; pastörizasyon posa suyu ve mikrodalga posa suyu örneklerinde ise sırasıyla 5.4 ve $7.4^{\circ} \mathrm{B}$ olarak belirlenmiştir. Posa örneklerinin briks değerlerinin havuç suyu örneklerinden daha yüksek olduğu gözlemlenmiştir. Pas. P. S. örneklerinde yaklaşık \%52'lik bir azalma meydana gelirken, Mik. P. S. örneklerinde ise yaklaşık \%34'lük bir azalma meydana gelmiştir. Mikrodalga uygulamasının pastörizasyon uygulamasına göre briks değerlerini daha iyi koruduğu belirlenmiştir. İstatistiksel olarak incelendiğinde ise uygulamalar arasındaki farklılıklar önemli bulunmuştur $(p<0.05)$. Mikrodalga güç seviyesinin artışı ile örneklerin briks değerinde azalma meydana gelebileceği ifade edilmiştir (Sezer, 2014). Yapılan çalışmada, pastörizasyon ve mikrodalga örneklerinin toplam titrasyon asitliği değerlerine bakıldığında, en yüksek değer ısıl işlem görmemiş kontrol örneğinde sitrik asit cinsinden 0.54 $\mathrm{g} / 100 \mathrm{ml}$ olarak bulunmuştur. Isıl işlem gören örneklerde ise (Past. P. S. ve Mik. P.S) titrasyon asitliği değerleri sitrik asit cinsinden sırasıyla 0.28$0.29 \mathrm{~g} / 100 \mathrm{ml}$ olarak belirlenmiştir. Titrasyon asitliği değerlerinde ısıl işlem uygulaması ile yaklaşık \%48 azalma meydana gelmiştir. Havuç örneklerine ısıl işlem uygulandığında toplam asitliğin azaldığı tespit edilmiştir. İstatistiksel olarak incelendiğinde ise uygulamalar arasındaki farklılıklar önemli bulunmuştur $(p<0.05)$. Çalışmada, \% nem değerleri pastörizasyon örneklerinde 97.58-96.01, mikrodalga örneklerinde ise 97.02-94.58 arasında değişmiştir. Verilere göre en düşük değer kontrol (\% 88.46), en yüksek değer pastörize havuç suyu (\%97.58) örneğinde bulunmuştur (Şekil 1). Yapılan ısıl işlemlerde ise mikrodalga ve pastörizasyon örneklerindeki \% nem miktarının arttığı tespit edilmiştir.

Gıdadaki su miktarı arttıkça kuru madde oranının azaldığı, su miktarı azaldıkça da kuru madde oranının arttığı bilinmektedir. Kuru madde oranındaki artışın nedeninin hacimsel ısıtma ile ürünün içten kuruması sonucu yapıdaki su miktarının azalmasından kaynaklanabileceği bildirilmiştir (Muftigil, 1984).

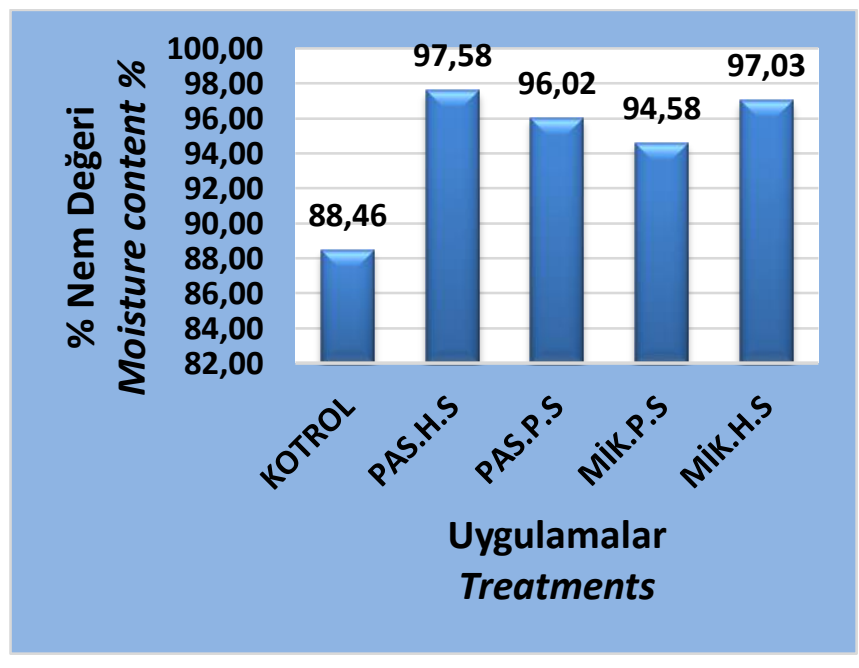

Şekil 1. Havuç suyu örneklerinin \% nem değerleri

Figure 1. \% Moisture values of carrot juice samples

Çalışmada, ısıl işlem uygulaması ile toplam fenolik madde miktarının azaldığı belirlenmiştir (Çizelge 2). Kontrol örneğine göre, en düşük değer pastörize havuç suyunda $64.43 \mathrm{mg} \mathrm{l}^{-1}$ gallik asit eşdeğeri, en yüksek değer ise mikrodalga posa suyunda $256.70 \mathrm{mg} \mathrm{l}^{-1}$ gallik asit eşdeğeri olarak bulunmuştur. Isıl işlem uygulaması ile Pas. P. S. örneklerinde \%93, Mik. P. S. örneklerinde ise \%87.4'lük bir azalma meydana gelmiştir. Genel olarak bakıldığında havuçların posa sularındaki fenolik madde miktarlarının daha fazla olduğu aynı zamanda suya da bir miktar fenolik maddenin geçebileceği düşünülmektedir. İstatistiksel olarak incelendiğinde ise uygulamalar arasındaki farklııklar önemli bulunmuştur $(p<0.05)$. Çağındı (2016), “mikrodalga uygulamasının kırmızı üzüm suyunun antosiyanin içeriği ile bazı fizikokimyasal özellikleri üzerine etkisi" konulu yapmış olduğu çalışmasında, kırmızı üzüm suyu örneklerinde toplam fenolik madde miktarının mikrodalga uygulamasıyla birlikte azaldığını ifade etmiştir. Demirdöven ve Baysal (2008) tarafından nar suyu üzerine yapılan çalışmada da berrak nar sularına uygulanan mikrodalga ile ısıtma uygulaması sonucu toplam fenolik madde içeriğinde azalma 
tespit edilmiştir.

Toplam flavonoid madde miktarına bakıldığında, en yüksek değer ısıl işlem uygulanmayan taze havuç suyu örneğinde 38.45 $\mathrm{mg} \mathrm{l}^{-1}$ kateşol eşdeğeri olarak bulunmuştur.

Uygulanan Isıl işlemle birlikte mikrodalga posa suyunda \%9.8'lik azalma, pastörize posa suyunda ise \% 9.8'lik azalma tespit edilmiştir.

En düşük değerlerin sırasıyla pastörize havuç suyu (11.23 $\mathrm{mg} \mathrm{l}^{-1}$ ) ve mikrodalga havuç suyuna (13.11 $\mathrm{mg} \mathrm{l}^{-1}$ ) ait olduğu belirlenmiştir.

Sonuçlar göz önüne alınarak, ısıl işlemle birlikte suya geçen flavonoid madde miktarının fazla olduğunu söylemek mümkün olabilir.
İstatistiksel olarak incelendiğinde ise uygulamalar arasındaki farklılıklar önemli bulunmuştur (Çizelge 2) ( $p<0.05)$.

Antioksidan aktivite tayininde ise, en yüksek değer pastörize havuç suyu (\%76.85) örneğinde belirlenmiştir.

En düşük değerin ise (\%48.28) mikrodalga posa suyuna ait olduğu tespit edilmiştir. Sonuçlara bakıldığında havuç sularında antioksidan aktivitenin daha yüksek olduğu saptanmıştır. İstatistiksel olarak incelendiğinde ise uygulamalar arasındaki farklılıklar önemli bulunmuştur $(p<0.05)$.

Çizelge 2. Siyah havuç suyunun toplam fenolik madde, toplam flavonoid, antioksidan aktivite, askorbik asit ve toplam monomerik antosiyanin miktarı ve HMF üzerine uygulamaların etkisi

Table 2. Effect of applications on total phenolics, total flavonoid, antioxidant activity, ascorbic acid and total monomeric anthocyanin and HMF in black carrot juice.

\begin{tabular}{|c|c|c|c|c|c|c|}
\hline $\begin{array}{l}\text { Uygulamalar } \\
\text { Applications }\end{array}$ & $\begin{array}{l}\text { Toplam fenolik } \\
\text { madde } \\
\left(\mathrm{mg} \mathrm{l}^{-1}\right) \\
\text { Total phenolics } \\
\left(\mathrm{mg} \mathrm{l}^{-1}\right)\end{array}$ & $\begin{array}{l}\text { Toplam } \\
\text { flavonoid } \\
\left(\mathrm{mg} \mathrm{l}^{-1}\right) \\
\text { Total } \\
\text { flavonoids } \\
\left(\mathrm{mg} \mathrm{l}^{-1}\right)\end{array}$ & $\begin{array}{c}\text { Antioksidan } \\
\text { Aktivite } \\
\text { (\%DDPH } \\
\text { Inhibisyonu) } \\
\text { Antioxidant } \\
\text { activity (DPPH } \\
\text { Inhibition \%) } \\
\end{array}$ & $\begin{array}{l}\text { Askorbik asit } \\
\left(\mathrm{mg} \mathrm{l}^{-1}\right) \\
\text { Ascorbic acid } \\
\left(\mathrm{mg} \mathrm{l}^{-1}\right)\end{array}$ & $\begin{array}{c}\text { Toplam } \\
\text { monomerik } \\
\text { antosiyanin } \\
\left(\mathrm{mg} \mathrm{l}^{-1}\right) \\
\text { Total monomeric } \\
\text { anthocyanins } \\
\left(\mathrm{mg} \mathrm{l}^{-1}\right)\end{array}$ & $\begin{array}{c}\mathrm{HMF} \\
\left(\mathrm{mg} \mathrm{l}^{-1}\right) \\
H M F \\
\left(m g l^{-1}\right)\end{array}$ \\
\hline KONTROL & $2041.24 \pm 61.86^{a}$ & $38.45 \pm 2.73^{a}$ & $74.14 \pm 0.27^{c}$ & $123.27 \pm 2.69^{a}$ & $30.60 \pm 3.47^{d}$ & $94.19 \pm 7.55^{b}$ \\
\hline PAS. H.S. & $64.43 \pm 9.79^{d}$ & $11.23 \pm 0.41^{d}$ & $76.85 \pm 0.34^{a}$ & $37.60 \pm 1.06^{d}$ & $50.03 \pm 2.71^{c}$ & $74.40 \pm 5.48^{b}$ \\
\hline PAS. P.S. & $143.81 \pm 1.55^{c}$ & $17.80 \pm 0.02^{c}$ & $65.38 \pm 0.11^{d}$ & $78.85 \pm 0.19^{c}$ & $93.23 \pm 4.01^{a}$ & $128.20 \pm 22.32^{\mathrm{a}}$ \\
\hline Mik. P.S. & $256.70 \pm 2.01^{b}$ & $34.68 \pm 3.05^{b}$ & $48.28 \pm 0.54^{\mathrm{e}}$ & $110.91 \pm 10.62^{b}$ & $79.56 \pm 5.53^{b}$ & $134.51 \pm 17.80^{\mathrm{a}}$ \\
\hline Mik. H.S. & $106.70 \pm 12.89^{d}$ & $13.11 \pm 0.89^{d}$ & $75.70 \pm 0.54^{b}$ & $41.83 \pm 1.06^{d}$ & $1.08 \pm 2.17^{e}$ & $76.55 \pm 19.25^{b}$ \\
\hline
\end{tabular}

Üretim aşamalarındaki (sütunlarda) farklı küçük harfler ile gösterilen örnekler asındaki farklılıklar 0.05 düzeyinde önemlidir.

The differences between samples indicated by lower-case letters in production stages (columns) are important at the 0.05 level.

Pastörize havuç suyu: PAS. H.S., Pastörize possa suyu: PAS. P.S., MiK. P.S.: Mikrodalga possa suyu, MiK. H.S.: Mikrodalga havuç suyu

Pasteurized carrot juice: PAS. H.S., Pasteurize pulp water: PAS. P.S., MIK. P.S .: Microwave pulp water, MIK. H.S .: Microwave carrot juice

Rossi ve ark. (2003)'nın yaban mersini üzerine yaptıkları araştırmada yaban mersinlerinde suda haşlama ön işlemi uygulayarak antioksidan süpürme aktivitesindeki (DPPH) değişimi incelemişlerdir. Suda haşlanmış örneklerdeki antioksidan süpürme aktivitesinin işlem görmemiş örneklere göre artış gösterdiği tespit edilmiştir. Yukarıda ifade edilen tüm bu çalışmalarda meyve ve sebzelerin yapısında doğal olarak bulunan bazı önemli oksidatif enzimlerin ısıl işlemlerle inaktive edilerek fenolik, karotenoid gibi antioksidan özellikteki kimyasal maddelerin parçalanmasını engellediği ve bundan dolayı da antioksidan aktivitenin korunduğu vurgulanmaktadır (Rossi, 2003; Olivera, 2008; Türkmen, 2005). Çalışmada en yüksek askorbik asit miktarı ısıl işlem görmemiş kontrol örneğinde $123.27 \quad \mathrm{mg} \quad \mathrm{I}^{-1}$ olarak belirlenmiştir. Isıl işlem uygulandığında mikrodalga posa suyunda $110.91 \mathrm{mg} \mathrm{l}^{-1}$ (\%10'luk azalma) ve pastörize posa suyu $78.85 \mathrm{mg} \mathrm{l}^{-1}$ (\%36'lık azalma) olarak bulunmuştur. En düşük değerler sırasıyla pastörize havuç suyu $37.60 \mathrm{mg} \mathrm{l}^{-1}$ ve mikrodalga havuç suyu $41.83 \mathrm{mg} \mathrm{l}^{-1}$ olarak bulunmuştur.

Sonuç olarak askorbik asit miktarının en çok posa sularına geçtiği belirlenmiştir. İstatistiksel olarak incelendiğinde uygulamalar arasındaki farklılıklar önemli bulunmuştur (Çizelge 2) $(p<0.05)$. Bazı tropikal yeşil yapraklı sebzelerin antioksidan özellikleri üzerinde haşlama işleminin etkisi araştırılmış, haşlamanın sebzelerin C vitamini içeriğinde önemli bir azalmaya neden olduğu, bu kaybın C vitaminin suda kolay çözünür ve yüksek 
sıcaklıklarda stabil olmadığından kaynaklandığı bildirilmiştir (Oboh, 2005). Isı hassasiyeti, suda çözünürlüğünün yüksek derece olması ve bozulabilir vitamin olmasından dolayı, askorbik asidin endüstriyel işleme sırasında zarara uğramasının tazelik ve kalitenin mükemmel bir indikatörü olduğu belirtilmiştir (Tapadia, 1995).

Yapılan çalışmada, toplam monomerik antosiyanin miktarları en fazla pastörize posa suyunda $93.23 \mathrm{mg} \mathrm{l}^{-1}$ ve mikrodalga posa suyunda $79.56 \mathrm{mg} \mathrm{l}^{-1}$ bulunmuştur. En düşük değer ise mikrodalga havuç suyu $1.08 \mathrm{mg} \mathrm{l}^{-1}$ değerinde bulunmuştur (Çizelge 2) İstatistiksel olarak incelendiğinde ise uygulamalar arasındaki farklılıklar önemli bulunmuştur ( $p<0.05)$.

Antosiyanin miktarında gözlenen bu artışın, pektinin parçalanması sonucu antosiyaninlerin serbest kalmasından kaynaklandığı düşünülmektedir (Özkan, 2009). Ön işlem uygulanmamış örneklerde antosiyanin miktarının ön işlem uygulanmış olanlara göre düşük çıkmasının nedeninin, taze örneklerde doğal olarak bulunan fenoloksidaz enzimlerinin ürünün parçalanması ile birlikte antosiyanin gibi fenolikleri substrat olarak kullanarak onları parçalamasından kaynaklanabileceği söylenebilir. Isıl işlemlerle birlikte bu enzimler inaktive edilmek suretiyle toplam monomerik antosiyanin miktarının korunabileceği düşünülmektedir (Demir, 2010).

$\mathrm{Bu}$ çalışmada, ısıl işlem görmeyen kontrol örneğinde HMF miktarı $94.19 \mathrm{mg} \mathrm{l}^{-1}$ olarak tespit edilmiştir. HMF miktarında en yüksek değer ısıl işlem görmüş mikrodalga posa suyunda $134.51 \mathrm{mg}$ $\mathrm{I}^{-1}$ bulunmuştur. Bu örnekte kontrol örneğine ile karşılaştırıldığında HMF miktarında \%43 artış tespit edilmiştir. Pastörize posa suyunda ise HMF miktarında \%37 artış meydana gelmiştir. En düşük HMF değeri ise pastörize havuç suyunda (74.4 mg $\mathrm{I}^{-1}$ ) belirlenmiştir (Çizelge 2).

HMF miktarı, posa suyu örneklerinde yüksek havuç suyu örneklerinde ise daha düşük çıkmıştır. HMF gıdaların tadında, renginde ve kokusunda istenmeyen değişikliklere neden olmaktadır ve gıdaya uygulanan ısının bir göstergesi olarak bilinmektedir (Cemeroğlu, 2017). İstatistiksel olarak incelendiğinde ise uygulamalar arasındaki farklılıklar önemli bulunmuştur ( $p<0.05)$.

Yapılan çalışmada, L*değeri göz önüne alınarak, en parlak kontrol örneği, parlaklığı en düşük olan örnek ise mikrodalga posa suyu olarak belirlenmiştir. +a* en yüksek (kırmızılık) pastörize posa suyunda (0.12) bulunurken -a*değeri en fazla (yeşillik) mikrodalga posa suyunda (0.02) tespit edilmiştir. +b* (sarılık) değeri en fazla kontrol örneğinde (0.29) iken -b* değeri (mavilik) değeri mikrodalga posa suyunda (0) bulunmuştur (Şekil 2). Hue değeri en yüksek kontrol örneğinde (68.25) iken en düşük mikrodalga posa suyunda (0) tespit edilmiştir. Kroma değeri en yüksek değer olarak kontrol örneğinde (0.31), en düşük mikrodalga posa suyu (0.02) örneğinde tespit edilmiştir.

İstatistiksel olarak incelendiğinde ise uygulamalar arasındaki farklılıklar önemli bulunmuştur (Şekil 3) $(p<0.05)$. Pastörizasyon ve mikrodalga uygulaması ön işlemleri ile $L^{*}$ değerinde azalma olması örneklerin parlaklığında kısmi bir azalmanın göstergesi olarak bilinmektedir (Olivera, 2008).

a* renk değerinin artmış olması örneklerin ön işlemlerle renginin kırmızılaştığının veya doğal kırmızı renginin korunduğunun bir göstergesi olarak kabul edilebilir.

Rossi ve ark. (2003), yaban mersinine uygulanan haşlama işlemi ile hue açısı değerlerinde bir azalmanın meydana geldiğini tespit etmişler ve bu değerin düşük çıkmasının nedeninin $b^{*}$ ve $a^{*}$ değerindeki düşüşle ilgili olduğunu belirtmişlerdir.

$L^{*}$ (parlaklık) değerlerinin yanı sıra $a^{*}$ (kırmızıyeşil), b* (sarı-mavi) değerlerinin geleneksel haşlanan örneklerde daha yüksek olduğu, depolamadan sonra mikrodalga uygulanan örneklerin parlaklık $\left(L^{*}\right)$ değerlerinin daha iyi renk sonuçları verdiği bildirilmiştir.

Materyalin çeşidine göre renk değerlerindeki değişimlerin farklılık gösterdiği belirtilmiştir (Sezer ve Demirdöven, 2015). 


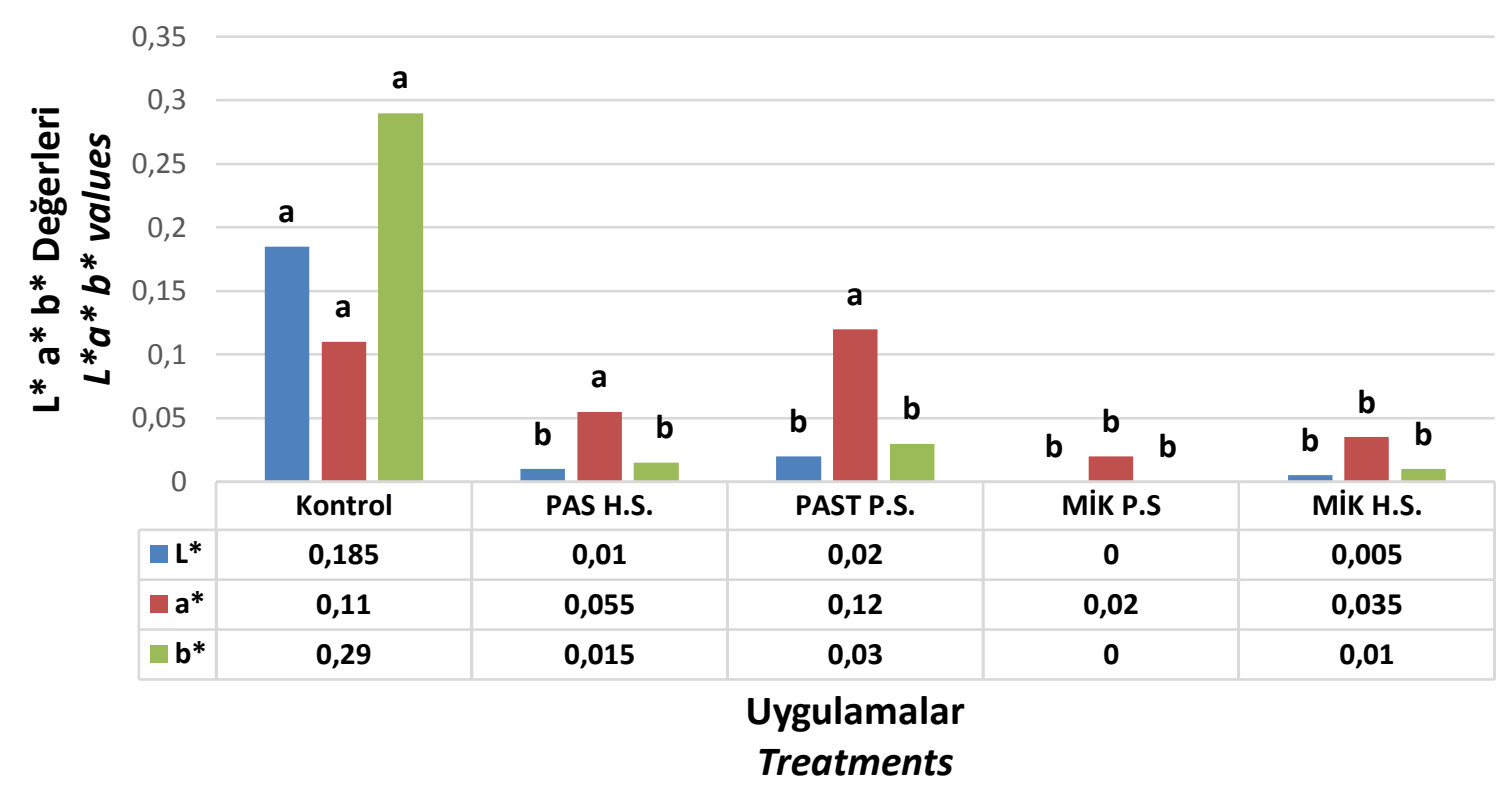

Şekil 2. Havuç suyu örneklerine ait $L^{*}, a^{*}$ ve $b^{*}$ değerleri

Figure 2. $L^{*}, a^{*}$ and $b *$ values of carrot juice samples

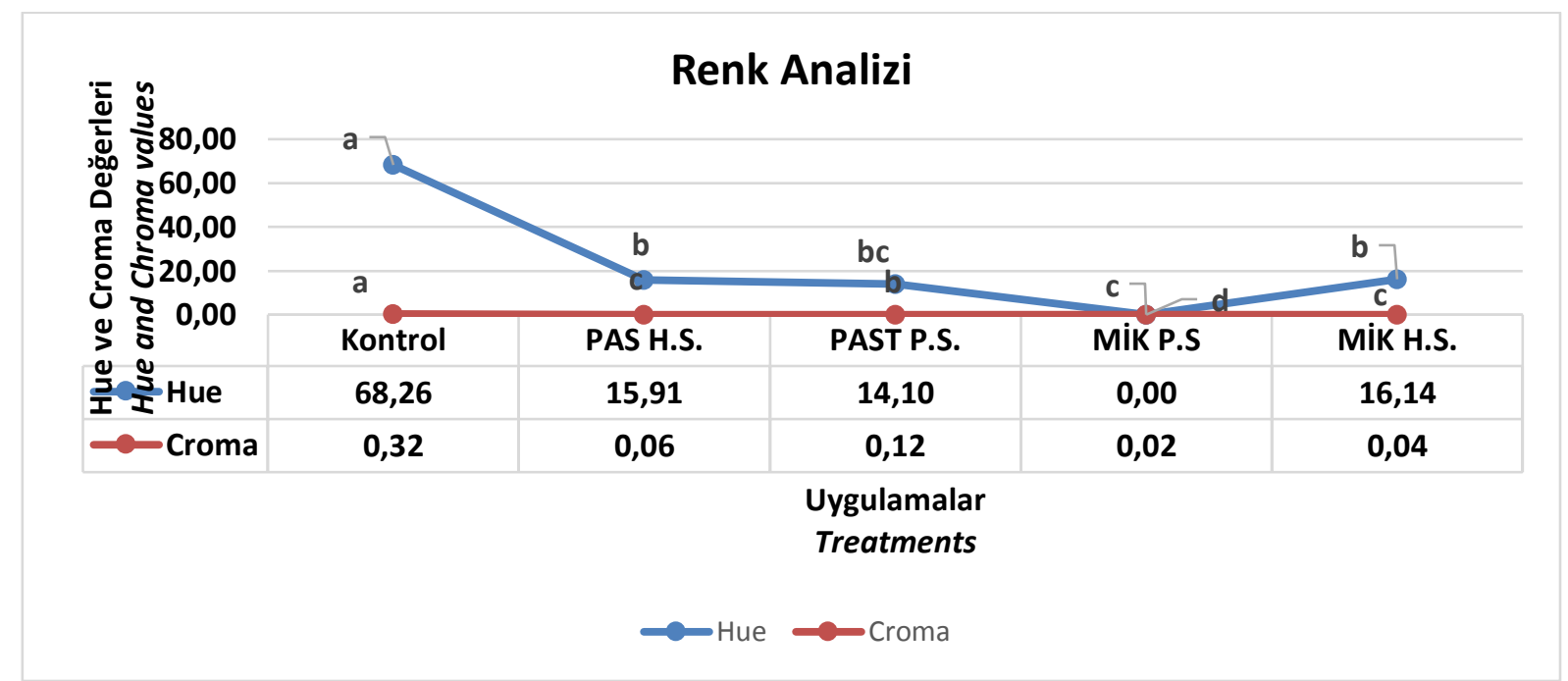

Şekil 3. Havuç suyu örneklerine ait Hue ve croma değerleri

Figure 3. Hue and croma values of carrot juice samples

\section{Sonuç ve Öneriler}

Çalışmamızda siyah havuç, pastörizasyon uygulamasında $98^{\circ} \mathrm{C}$ sıcaklıkta ve mikrodalga haşlamada ise $1000 \mathrm{~W}$ güçte ısıl işleme tabi tutulmuştur.

Siyah havucun yapısında doğal olarak bulunan ve kimyasal yapı üzerinde önemli etkileri olan peroksidaz enzimini inaktif etmek amacıyla, pastörizasyon ve mikrodalga uygulaması olmak üzere iki farklı ön işlem uygulanmıştır.

Bu işlemlerin sonucunda POD, $\mathrm{pH}$ değeri, SÇKM, toplam titrasyon asitliği, \% nem miktarı, askorbik asit, toplam fenolik madde miktarı, toplam flavonoid madde miktarı, toplam monomerik antosiyanin miktarı, antioksidan kapasite değeri, renk ve HMF analizleri yapılmıştır. Havucun yapısındaki değişimler incelenmiş ve bu kalite parametrelerine en az etki eden yöntem ve işlem belirlenmiştir. Bu çalışma, siyah havuca pastörizasyon ve mikrodalga uygulaması ile meyve sebze endüstrisine katkı sağlanması açısından önem taşımaktadır.

Ayrıca bu çalışma siyah havuca uygulanan pastörizasyon ve mikrodalga yöntemlerinin karşılaştırılması ve meyve sebze işleme sanayine uygun yöntem ve koşulların belirlenmesi açısından da önemlidir. Pastörizasyon yöntemi ile havuçlardan elde edilen analiz sonuçları mikrodalga uygulama değerleri ile karşılaştırılarak mikrodalganın avantaj ve dezavantajları belirlenmiştir. POD gibi önemli bir enzimi inaktif edecek ön işlemlerin uygulanmasının siyah havucun kimyasal yapısı üzerine etkilerinin olduğu 
sonucuna varılmıştır. POD inaktivasyonu için gerekli mikrodalga süresinin, pastörizasyona göre altı kat daha kısa sürdüğü tespit edilmiştir.

En yüksek pH değeri kontrol örneğinde, en düşük $\mathrm{pH}$ değeri ise mikrodalga posa suyunda tespit edilmiştir. Posa örneklerinin briks değerlerinin havuç suyu örneklerinden daha yüksek olduğu gözlemlenmiştir. Havuç örneklerine ısıl işlem uygulandığında toplam asitliğin azaldığı tespit edilmiştir. Havuçların posa sularındaki fenolik madde miktarlarının daha fazla olduğu aynı zamanda suya da bir miktar fenolik maddenin geçtiği gözlemlenmiştir. Toplam flavonoid miktarının ısıl işlem uygulanmayan taze havuç suyu örneğinde en yüksek değer olarak bulunduğu tespit edilmiştir. Antioksidan kapasite değeri için en yüksek değer pastörize havuç suyu örneğinde bulunmuştur. Isıl işlem uygulanmayan kontrol örneğinde askorbik asit miktarının fazla olduğu, ısıl işlem uygulandığında ise askorbik asit miktarının azaldığı tespit edilmiştir. Toplam monomerik antosiyanin miktarı ise en fazla pastörize posa suyunda bulunmuştur. HMF miktarı, posa suyu örneklerinde yüksek havuç suyu örneklerinde ise daha düşük çıkmıştır.

Örneklerin $a^{*}$ ve $b^{*}$ renk değerlerinde artışlar tespit edilmiştir. Pastörizasyon ve mikrodalga yöntemlerini beraber kullanarak enzim inaktivasyonunu incelemenin, hem çalışmanın devamı olması açısından fayda sağlayacağı hem de yapılacak çalışma sonucunda elde edilen verilerin literatüre katkı sağlayabileceği düşünülmektedir.

\section{Ekler}

Bu çalışmanın gerçekleştirilmesinde katkılarını esirgemeyen Kilis 7 Aralık Üniversitesi'ne teşekkür ederiz.

\section{Kaynaklar}

Ağçam, E., Akyıldız, A., 2015. Siyah Havuç Posasından Antosiyaninlerin Ekstraksiyonuna Farklı Çözgen ve Asit Konsantrasyonlarının Etkileri. Gıda Dergisi/The Journal of Food, 40:(3).

AOAC., 2000. Official methods of analysis no 985.26 (17th edn), Washington, DC, Association of Official Analytical Chemists.

Benlloch-Tinoco, M., Igual, D. Ve Martínez-Navarrete, N., 2013. Comparison of Microwaves and Conventional Thermal Treatment on Enzymes Activity and Antioxidant Capacity of Kiwifruit Puree. Innovative Food Science and Emerging Technologies, 19: 166172.

2008. Inactivation Kinetics of Polyphenol Oxidase and
Cemeroğlu, B., 1992. Meyve ve Sebze İşleme Endüstrisinde Temel Analiz Metotları. Biltav Yayınları, Ankara, $381 \mathrm{~s}$. Cemeroğlu, B., 2007. Gıda Analizleri. Gıda Teknolojisi Derneği Yayınları, No:34, Ankara.

Çağındı, Ö., 2016. Mikrodalga Uygulamasının Kırmızı Üzüm Suyunun Antosiyanin İçeriği ile Bazı Fizikokimyasal Özellikleri Üzerine Etkisi. Akademik Gıda, 14(4): 356361.

Demir, D., 2010. Kurutma İşlemi ve Öncesinde Uygulanan Farklı Haşlama Tekniklerinin Siyah Havucun Antioksidan Etkili Bileşikleri Üzerine Etkisi, Yüksek Lisans Tezi, Selçuk Üniversitesi Gıda Mühendisliği Anabilim Dalı, Konya, 65s.

Demirdöven, A., Baysal, T., 2008. Nar suyu üretiminde kabuklu ve kabuksuz presleme ile mikrodalga uygulamasının bazı kalite özellikleri üzerine etkileri. Akademik Gıda, 6(2): 7-12.

Dorantes-Alvarez, L., Parada-Dorantes, L., 2005. Blanching Using Microwave Processing. In: Microwave Processing of Foods, H. Schubert (Editor), Woodhead Publishing, Cambridge, pp. 153-172.

Fito, P., Chiralt, A., Martin, M.E., 2005. Current State of Microwave Applications to Food Precessing. In: Novel Food Processing Technology, G.V. Barbosa-Canovas, M.S. Tapia and M.P. Cano (Editors), CRC Press, Boca Raton, pp. 525-538.

Geçer, E.N., 2011. Farklı Pişirme Metotlarının Havucun Fitokimyasal Özelliklerine Etkisi. Yüksek Lisans Tezi, Gaziosmanpaşa Üniversitesi Fen Bilimleri Enstitüsü Gıda Mühendisliği Anabilim Dalı, Tokat, 57s.

Giusti, M.M., Wrolstad, R. E., 2001. Characterization and measurement with UV-visible spectroscopy. In Current Protocols in Food Analytical Chemistry. R. E. Wrolstad, S. J. Schwartz (Eds), John Wiley and Sons, New York, pp 1-13,

Gümüşderelioğlu, M., 2012. Polimer Bilim ve Teknolojisi Ders Notları, Hacettepe Üniversitesi.

Gould, A. W., 1977. Food Quality Assurance, The AVI Publishing Company İnc. USA, 314p.

Gil, M.I., Tomas-Barberan, F.A., Hess-Pierce, B., Holcroft, D.M., Kader, A. A., 2000. Antioxidant activity of pomegranate juice and its relationship with phenolic composition and processing. Journal of Agricultural and Food Chemistry, 48:4581-4589.

Hışıl, Y., 2004. Enstrümental Gıda Analizleri-Laboratuvar Deneyleri. Ege Üniversitesi, Mühendislik Fakültesi, Ders Kitapları, Bornova, İzmir, Yayın no: 45, 39 s.

Huang, D., Ou, B., Prior, R.L., 2005. The Chemistry Behind Antioxidant Capacity as Says. J. Agric. Food Res., 53: 1841-1856.

Kemahlıoğlu, K., Baysal, T., 2002. Hububat Ürünlerinin İşlenmesinde Mikrodalga Uygulamaları. Hububat Ürünleri Teknolojisi Kongre ve Sergisi, Gaziantep.

Lemmens, L., Tibäck, E., Svelander, C., Smout, C., Ahrné, L., Langton, M., 2009. Thermal Pretreatments of Carrot Pieces Using Different Heating Techniques: Effect on Quality Related Aspects. Innovative Food Science and Emerging Technologies, 10: 522-529.

Lin, S., Brewer, M.S., 2005. Effects of Blanchıng Method on The Quality Characteristics of Frozen Peas, Journal of Food Quality, 28: 350-360.

Matsui, K.N., Gut, J. A.W., De Oliveira, P.V., Tadini, C.C., Peroxidase in Green Coconut Water by Microwave 
Processing. Journal of Food Engineering, 88: 169-176.

Muftigil, N., 1984. Bazı Sebzelerin Peroksidaz Enzim İçerikleri ve Bu Enzimin Isıya Karşı Direnci. Gıda, 84: 4.

Murcia, M.A., Lopez-Ayerra, B., Martinez-Tome, M., Vera, A.M., Garcia-Carmona, F., 2000. Evolution of Ascorbic Acid and Peroxidase During Industrial Processing of Broccoli, Journal of The Science of Food ve Agriculture, 80: $1882-1886$.

Negi, P.S., Roy, S.K., 2000. Effect of Blanching and Drying Methods on $\beta$-Carotene, Ascorbic Acid ve Chlorophyll Retention of Leafy Vegetables, LebensmittelWissenschaft und Technologie, 33 (4): 295-298.

Oboh, G., 2005. Effect of Blanching on the Antioxidant Propetries of Some Tropical Green Leafly Vegetables, Science Direct, 38: 513-517.

Olivera, D. F., Vina, S. Z., Marani, C. M., Ferreyra, R. M., Mugridge, A., Chaves, A. R., Mascheroni, R. H., 2008. Effect of Blanching on the Quality of Brussels Sprouts After Frozen Storage, Journal of Food Engineering, 84: 148-155.

Özkan, M., 2009. Siyah Havuç Suyu Konsantresi Üretimi ve Depolanması Sürecinde Fenolik Maddeler ve Antosiyaninlerdeki Değişimler ve $\mathrm{Bu}$ Değişimlerin Antioksidan Aktivite ile İlişkisi. Ankara Üniversitesi Bilimsel Araştırma Projesi Kesin Raporu, Proje Numarası : 07B4343002, 106s.

Tangüler, H., 2010. Şalgam Suyu Üretiminde Etkili Olan Laktik Asit Bakterilerinin Belirlenmesi ve Şalgam Suyu Üretim Tekniğinin Geliştirilmesi. Çukurova Üniversitesi, Fen Bilimleri Enstitüsü, Gıda Mühendisliği Anabilim Dalı, Doktora Tezi, 367s.

Tomas-Barberan, F.A. ve Espin, J.C., 2001. Phenolic Compounds and Related Enzymes as Determinants of Quality in Fruits and Vegetables. Journal of the Science of Food and Agriculture, 81:853-876.

Rossi, M., Giussani, E., Morelli, R., Lo Scalzo, R., Nani, R. C., Torreggiani, D., 2003. Effect of Fruit Blanching on Phenolics and Radical Scavenging Activity of Highbush Blueberry Juice, Food Research International, 36: 9991005.

Sànchez-Moreno, C., Plaza, L., De Ancos, B., Cano, M. P.,
2003. Quantitative Bioactive Compounds Assessment and Their Relative Contributionto the Antioxidant Capacity of Commercial Orange Juices. Journal of Agricultural and Food Chemistry, 83: 430-439.

Sezer, D.B., 2014. Havuç Dilimlerinde Mikrodalga Haşlama Koşullarının Optimizasyonu, Gaziosmanpaşa Üniversitesi Yüksek Lisans Tezi, Tokat, $26 \mathrm{~s}$.

Sezer, D.B, Demirdöven, A., 2015. Meyve sebze işemede mikrodalga haşlama uygulamaları. Gıda Dergisi, 40 (3): 171-177.

Sharm, S., Vig P. A., 2013. Evaluation of in Vitro Antioxidant Properties of Methanol and Aqueous Extracts of Parkinsoniaaculeata L. Leaves. The Scientific World Journal, 1-7.

Soysal, Ç., Söylemez, Z., 2005. Kinetics and Inactivation of Carrot Peroxidase by Heat Treatment. Journal of Food Engineering, 68: 349-356.

Stanković, M.S., 2011. Total Phenolic Content, Flavonoid Concentration and Antioxidant Activity of Marrubiumperegrinum L. Extracts. Kragujevac J. Sci., 33: 63-72.

Tapadia, S.B., Arya, A.B., Rohini, D.P., 1995. Vitamin C Contents of Processed Vegetables, Food Science Technology india, 32:513-515.

Türkmen, N., Sari, F. ve Velioğlu, Y. S., 2005. The Effect of Cooking Methods on Total Phenolics and Antioxidant Activity of Selected Green Vegetables, Food Chemistry, 93:713-718.

Yemenicioğlu, A., Cemeroğlu, B., 1998. Enzimlerin Aktivasyon ve Rejenerasyonun Gıdaların Kalitesi Üzerine Etkileri. GIda, 23 (6):415-423.

Yılmaz, O. M., 2011. Determination of The Antioxidant Activity and Phenolic Acid Composition of Main Wheat Varieties Grown in Turkey and Enrichment of Bread with Pomegranate Husk Extract. PhDThesis. Ankara University, 80p.

Zheng, H., Lu, H., 2011. Effect of Microwave Pretreatment on the Kinetics of Ascorbic Acid Degradation ve Peroxidase Inactivation in Different Parts of Green Asparagus (Asparagus officinalis L.) During Water Blanching, Food Chemistry, 128, 1 